\title{
CEREBRAL VENOSUS SINUS THROMBOSIS IN A HEALTHY WOMEN TAKING ORAL CONTRACEPTIVE: A CASE REPORT AND REVIEW OF LITERATURE
}

\author{
Kamuran Kilavuz SUMAN' ${ }^{1}$, Behiye Pinar GOKSEDEF ${ }^{1}$, Bora KOC ${ }^{2}$ \\ ${ }^{1}$ Haseki Training and Research Hospital, Department of Obstetrics and Gynecology, Istanbul \\ 2 Okmeydani Training and Research Hospital, Department of General Surgery, Istanbul
}

\begin{abstract}
SUMMARY
Cerebral venous sinus thrombosis (CVST) is rare than arterial thrombosis. It can affect all age groups but is seen mostly in young women. The diagnosis of CVST is not easy because of variability of clinical symptoms and signs. The patients can present with headache, papilledema, focal deficit, seizures and coma. The most frequent symptom is severe headache. The most common causes of CVST are pregnancy, puerperium, systemic inflammatory diseases, inherited and acquired coagulation disorders, trauma, lumbar puncture, drugs and infection. The use of oral contraceptive (OC) increases the risk of cerebral sinus thrombosis. If there is an additional hereditary prothrombotic factor, the risk of CVST is more. CVST affects superior sagittal sinus and the lateral sinuses more frequently. More than one sinus is affected in one-third of cases. Computed tomografi helps to exclude other intracranial condition but diagnostic value of CT in CVST is limited. Combination of magnetic resonance imaging (MRI) and magnetic resonance venography (MRV) have replaced cerebral angiography for diagnosis of CVST. The treatment of CVST contain supportive (hydration, antibiotheraphy, anticonvulsant) and anticoagulan treatment. Heparin is effective and safety for the treatment of CVST because of this, it is the first-line treatment. The safety of heparin treatment also has been shown in those patients who had hemorrhagic infarcts. Outcomes of CVST is variable from death to complete improvement, but in general it is favorable. Recurrence of CVT is not common.

Herein we present a 33-years old previously healthy women with CVST who taking OC.
\end{abstract}

Key words: cerebral venosus sinus thrombosis, magnetic resonance imaging, oral contraceptive

Journal of Turkish Society of Obstetrics and Gynecology, (J Turk Soc Obstet Gynecol), 2013; Vol: 10, Issue: 2, Pages: 110- 3

\section{ORAL KONTRASEPTIFF KULLANAN SAĞLIKLI KADINDA SEREBRAL VENÖZ SINUS TROMBOZU: VAKA SUNUMU VE LITERATÜRÜN GÖZDEN GEÇiRILIMESİ}

\section{ÖZET}

Serebral venöz sinüs tromboz (SVST) arteriyel trombozdan daha nadirdir. Tüm yaş gruplarını etkileyebilir ancak daha çok genç kadınlarda görülür. Klinik semptom ve bulguların çeşitliliği nedeni ile SVST tanısı kolay değildir. Hastalar baş ăgrısı, papilödem, fokal defisit, kasılmalar ve koma gibi bulgularla gelebilir. En sık semptom şiddetli baş ağrısıdır. En sık nedenler gebelik, lohusalık, sistemik inflamatuar hastalıklar, kalıtımsal ve edinilmiş pıhtılaşma bozuklukları, travma, lomber ponksiyon, ilaçlar ve enfeksiyondur. Oral kontraseptif (OK) kullanımı serebral sinüs trombozu riskini arttırır. Ĕger ek kalıtsal protrombotik faktör var ise, sinüs ven trombozu riski daha fazladır. SVST en çok superior sagittal sinüs ve lateral sinüslerde görülür. Vakaların üçte birinde, birden fazla sinüs etkilenmiştir. Bilgisayarlı tomografinin SVST'daki tanısal değeri sınırlıdır ancak diğer intrakranial durumların dışlanmasında yardımcı olur. Manyetik rezonans görüntüleme (MRG) ve manyetik rezonans venografinin kombinasyonu SVST

Address for Correspondence: Dr. Kamuran Kılavuz Suman. Haseki Eğitim ve Araştırma Hastanesi, İstanbul Phone: + 90 (505) 3556520

e-mail: kamuransuman@gmail.com

Received: 11 June 2012, revised: 27 November 2012, accepted: 09 January 2013, online publication: 10 January 2013 
tanısında serebral anjiografinin yerini almıştır. SVST tedavisi destek tedavisi (hidrasyon, antibioterapi, antikonvulzan) ve antikoagulan tedavilerini içerir. Heparin tedavisi, SVST tedavisi iç in etkili ve güvenilirdir. Bu nedenle ilk basamak tedavi olarak bildirilmektedir. Heparin tedavisinin hemorajik infarktı olan hastalarda bile güvenli olduğu gösterilmiştir. SVST sonuç ları ölümden tamamen iyileșmeye kadar değişkendir, ancak genel olarak olumludur. SVST rekürrensi sık değildir. Biz 33 yaşında daha öncesinde sağlıklı olup, OK kullanan ve SVST gelişen bir bayan hasta sunmak istedik.

Anahtar kelimeler: manyetik rezonans, oral kontraseptif, serebral venöz sinüs trombozu

Türk Jinekoloji ve Obstetrik Derneği Dergisi, (J Turk Soc Obstet Gynecol), 2013; Cilt: 10, Sayl: 2, Sayfa: 110- 3

\section{INTRODUCTION}

Cerebral venosus sinus thrombosis (CVST) does not have much prevelance but can cause serious damage. The diagnosis of CVST is not easy because of variability of clinical symptoms and signs. Frequently superior sagittal sinus, transverse sinuses, sigmoid sinuses, cavernous sinus ve sinus rectus are effected(1). Can be seen at any age but mostly young adults are affected. Prevelance is three times higher in women comparing to men ${ }^{(2)}$. The most common causes are pregnancy, oral contraceptive usage and puerperium ${ }^{(3-6)}$. Systemic inflammatory diseases, inherited and acquired coagulation disorders, trauma, infection, severe anemia, connective tissue disorders and malignancy are the other predisposing diseases. Despite all researches, \%20-25 of patients doesn't have any risk factors ${ }^{(7)}$.

Epidemiologic studies show that oral contraceptive pills increases the risk of venous thromboembolism (deep vein thrombosis and pulmonary thromboembolism) ${ }^{(8)}$. Cerebral venous thrombosis is rare but related with using oral contraceptive in healty women, especially women with hereditary thrombophilia have

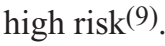

\section{CASE}

31-year-old patient was admitted to norology clinic with headache increasing at night and tremor at right hand. The patient reported that symtoms for the last 1 week. Patient has 1 vaginal birth and no history of disease.

Arterial blood pressure was $120 / 75 \mathrm{mmHg}$ and pulse was $80 / \mathrm{min}$, systemic examination revealed no abnormality. There was no neurologic deficit detected either. Also blood tests showed no pathology.

Cranial structures were normal at MR imaging, but
MR venography determined cutting of image of left transvers sinus that could be the thrombosis (Figure $1)$.

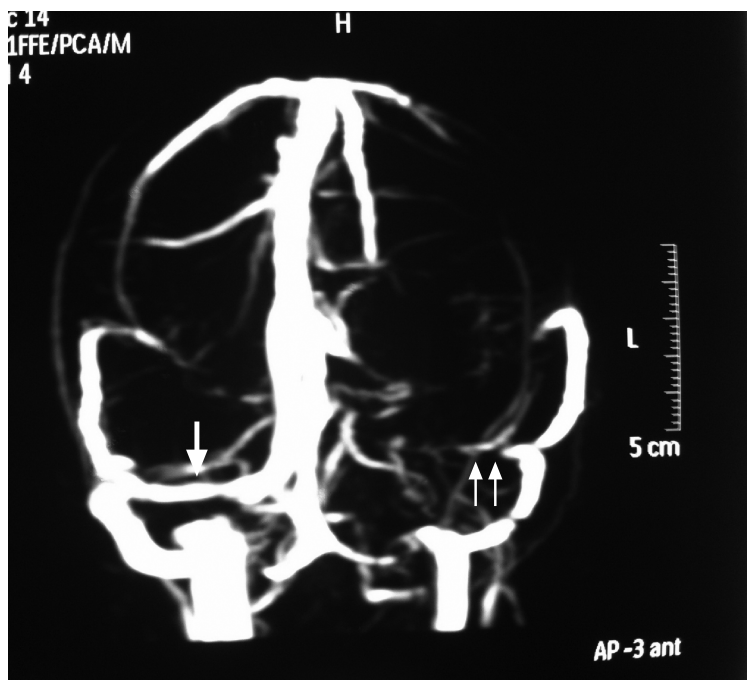

Figure 1: MRV-Left transverse sinus thrombosis (the downward arrow: normal right transverse sinus, the upward arrows: thrombosed left thasverse sinus)

When we refocused the patient's history, we learned that she was taking oral contraceptive included 0.02 $\mathrm{mg}$ etinilestradiol ve $3 \mathrm{mg}$ drospirenon. With additional tests; Floresan anti-nükleer antibody (FANA), Perinuclear Anti-Neutrophil Cytoplasmic Antibodies (p-ANCA), Cytoplasmic antineutrophil cytoplasmic antibodies (c-ANCA), Anti-mitochondrial antibody (AMA), anticardiolipin antibodies IgM and IgG, Lupus anticoagulant were detected negative and Antitrombin III, Protein S, Protein C were in normal range. Also there was no Factor V Leiden mutation.

After the diagnose of left lateral sinus thrombosis, mediacation immediatly started with low molecular weight heparin and warfarin to keep the INR around 2,5. 5th day of anticoagulation treatment, patient fully recovered and followed-up. 


\section{DISCUSSION}

When we compare CVST and arterial thrombosis of brain, CVST is less common, but conversly arterial thrombosis CVST usually affecting young adults and children. Predicted incidence is 3-4 in a million.\%75 of adult patients are women ${ }^{(10)}$. Mortality and morbidity of CVST is \% $5-30$.

Pregnancy, usage oral contraceptive (OC) and puerperium increases frequency in women $(3,4,11)$. First, in $1970 \mathrm{~s}$ Buchanan and colleagues reported that OC increased the CVST incidance(12). A study made in 1993-94 in U.S.A showed that using OC was an independent risk factor ${ }^{(7)}$.

The risk of sinus thrombosis is 4.2 times more in women who are not pregnant but using OC (13). Many other studies done in recent years reported that using OC increases the risk of $\operatorname{CVST}^{(7,14,15)}$.

Risk may vary with the formula of the OC. The compilation that contains 13 research showed 3th generation OCs have risk of venous thrombosis 1.44 times more than 2 th generation of $\mathrm{OCs}^{(16)}$.

Our case had no abnormality in coagulation tests. The only risk factor was OC usage. In literatur OC usage with trombofilia have higher risk. A case control study done by Dutch group reported that in women using OC, hypercoagulable states increased the risk of CVST from 13 to $34^{(17)}$. The risk is 10 times more in patients with herediter trombofilia Factor 5 Leiden or Protrombin 20210 mutation. In the patients with these mutations and hyperhomocysteinemia, risk increases exponentially (18).

There are many other factors at etiopathogenesis. These factors are trauma, infection (otitis, sinusitis, meningitis), severe anemia, pregnancy, puerperium, dehydration, connective tissue disease (systemic lupus erythematosus etc), systemic disorders and malignancies. $\% 80$ of patients have predisposing factors (7).

The most frequent presenting symptom is headache like in our case. In the study made by Burjin et al., this ratio was \%95(19). Other symptoms are nausea, vomitting, hemiparesis, paresthesia, convulsion, loose of conciusness.

CVST affects superior sagittal sinus in \%62-80 of cases and lateral sinus in $\% 38-86 . \% 75$ of the cases, more than one sinus are effected. Our case had isolated left lateral sinus trombosis. Isolated single sinus thrombosis is rare, less than $\% 10^{(3)}$.

Especially admittance to emergency, first imaging is computer tomography (CT) usually not have high value of diagnostic. CT is helpful to exclude other diseases and pathologic only in $\% 10-20$ of the patients ${ }^{(20)}$. For now, most valuable diagnostic method is magnetic resonance imaging (MRI) with magnetic resonance venography (MRV). Like in our case, use with has high ability to diagnose CVST and rarely needs angiograpy ${ }^{(21)}$.

The basis of the treatment are anticoagulants and support therapy. Anticoagulant treatment continues for 3-6 months and reduces the mortality and recovery period. Anticonvulsants and medications to lower the brain pressure are used as support therapy. If the patient get worse and the herniation symtoms are present, surgical decompression could be used(22).

The factors that effect the prognosis of CVST are; age, coma, mental disorders, intracranial hemorrhage and convulsions. A study that analyzed the patients' long term prognosis affected by CVST, reported $\% 85$ of patients had no sequele, \%14 had non-cerebral thrombotic events, $\% 12$ had recurrent convulsions and in \%11 CVST developed a second time(23).

As a result,CVST is an important stroke reason in young persons. In premanauposal women, risk of sinus thrombosis is low and the incidence is predicted $4 / 106 /$ year. OC is one of the iatrogenic reasons. The relation with OC,deep vein thrombosis and thrombophilia is also same with cerebral sinus thrombosis. We should be remember that can be seen in women without a history of hypercoagulability. Patients that want to use OC must be informed for the risks.

\section{REFERENCES}

1. Renowden S. Cerebral venous sinus thrombosis. Eur Radiol 2004; 14: 215- 26 .

2. Ehtisham A, Stern BJ. Cerebral venous thrombosis- a review. Neurologist 2006; 12: 32-8.

3. Bousser MG, Chiras J, Bories J: Cerebral venous thrombus - a review of 38 cases. Stroke 1985; 16: 199- 213.

4. Dzialo AF, Black-Schaffer RM: Cerebral venous thrombosis in young adults: 2 case reports. Arch Phys Med Rehabil 2001; 82: $683-8$.

5. Holger A, Richard J: Cerebral venous sinus thrombosis. 
Postgraduate Medical Journal 2000; 76: 891- 903.

6. Lanska DJ, Kryscio RJ: Stroke and intracranial venous thrombosis during pregnancy and puerperium. Neurolgy 1998; 51: $1622-8$

7. Lanska JD, RJ Kryscio. Risk factors for peripartum and postpartum stroke and intracranial venous thrombosis. Stroke 2000; 31(6): 1274- 82.

8. World Health Organization Collaborative Study of Cardiovascular Disease and Steroid Hormone Contraception. Venous thromboembolic disease and combined oral contraceptives: results of international multi centre casecontrol study. Lancet 1995; 346: 157582

9. Bertina RM, Rosendaal FR. Venous thrombosis-the interaction of genes and the environment. N Engl J Med 1998; 338: 18401.

10. Stam J. Current concepts: Thrombosis of the cerebral veins and sinuses. N Engl J Med 2005; 352: 1791- 8.

11. Zhang Z, Long J, Li W: Cerebral venous thrombosis: a clinical study of 23 cases. Chinese Medical Journal 2000;113 (11): $1043-45$.

12. Buchanan DS, Brazinsky JH. Dural sinus and cerebral venous thrombosis: incidence in young women receiving oral contraceptives. Arch Neurol 1970; 22: 440- 4.

13. Mancia D, Buccino G, Scoditti U, Pini M, Taqliqfem AR. Low-oestrogen oral contraceptives as a major risk factor for cerebral venous and sinus thrombosis: evidence from a clinical series. Ital J Neurol Sci 1999; 20: 231- 5.

14. Martinelli I, Landi G, Merati G, Cella R, Tosetto A, Mannucci PM. Factor V gene mutation is a risk factor for cerebral venous thrombosis. Thromb Haemost 1996; 75: 3934.

15. Martinelli I, Rosendaal FR, Vandenbroucke JP, Mannucci PM. Oral contraceptives are a risk factor for cerebral vein thrombosis [letter]. Thromb Haemost 1996; 76: 4778.

16. Vandenbroucke JP, Rosing J, Bloemenkamp KW, Middeldorp $\mathrm{S}$, Helmerhorst FM, Bouma BN, et al. Oral contraceptives and the risk of venous thrombosis. The N Engl J Med 2001; 344: 1527- 35 .

17. De Brujin SF, Stam J, Koopman MM, Vendenbroucke JP. Case-control study of risk of cerebral sinus thrombosis in oral contraceptive users who are carriers of hereditary prothrombotic conditions. BMJ 1998; 316: 589- 92.

18. Martinelli I, Battaglioli T, Pedotti P, Cattaneo M, Mannucci PM. Hyperhomocysteinemia in cerebral vein thrombosis. Blood 2003; 102: 1363- 6 .

19. Stam J, Bienfait HP, Lensing AWA: Anticoagulant treatment for cerebral venous thrombosis: A retrospective study of 53 cases. J. Neurol 1990; 237: 1286- 91.

20. Damak M, Crassard I, Wolff V, Bousser MG. Isolated lateral sinus thrombosis: a series of 62 patients. Stroke. 2009 Feb; 40(2): 476- 81 .

21. Masuhr F, Mehraein S, Einhaupl K. Cerebral venous and sinus thrombosis. J Neurol 2004; 251: 11- 23.

22. Ferro JM, Canhao P, Stam J: Prognosis of cerebral vein and dural sinus thrombosis: Result of the international study on cerebral vein and dural sinus thrombosis. Stroke 2004; 35: 664- 70.

23. Preter M, Tzourio C, Ameri A: Long term prognosis in cerebral venous thrombosis. Stroke 1996; 27: 243- 6. 